\title{
Meningkatkan Hasil Belajar Materi Bercerita Dengan Kalimat Efektif Dengan Menerapkan Pendekatan Communicative Language
}

\author{
Siti Romzah \\ SDN Airlangga I/198 Surabaya \\ Jl. Gubeng Airlangga I No. 2, Kecamatan Gubeng, Kota Surabaya \\ romzah20@gmail.com
}

\begin{abstract}
This study aims to determine whether nor not there is an increase in learning outcomes in storytelling material with effective sentences through the application of the Communicative Language Approach to Grade 5 students of SD Negeri Airlangga I/198 Surabaya, and to find out how much improvement in learning outcomes in storytelling materials with effective sentences through the application of this approach. Communicative Language for Grade 5 students of SD Negeri Airlangga I/198 Surabaya. Teachers are required to be able to adapt, choose and integrate various types of approaches and learning approaches in delivering material. This aims to make it easier for students to accept the material presented and avoid student boredom, so it is hoped that using the Communicative Language Approach in this thematic learning can improve understanding of Storytelling Materials with effective sentences for Class 5 students of SD Negeri Airlangga I/198 Surabaya. Action research was carried out in two learning cycles by applying the Communicative Language Approach and student learning outcomes on storytelling material with effective sentences as the object of research. Based on the explanation of the results of the research and discussion, it can be concluded that there is an increase in learning outcomes of storytelling materials with effective sentences through the application of the Communicative Language Approach to the 5th Graders of SD Negeri Airlangga I/198 Surabaya.
\end{abstract}

Keywords: Storytelling, Standard Language, Approach, Communicative Language

\begin{abstract}
Abstrak
Penelitian ini bertujuan untuk mengetahui ada tidaknya peningkatan hasil belajar pada materi Bercerita dengan kalimat efektif melalui penerapan Pendekatan Communicative Language pada siswa Kelas 5 SD Negeri Airlangga I/198 Surabaya, dan untuk mengetahui seberapa besar peningkatan hasil belajar pada materi Bercerita dengan kalimat efektif melalui penerapan Pendekatan Communicative Language pada siswa Kelas 5 SD Negeri Airlangga I/198 Surabaya. Guru dituntut untuk mampu menyesuaikan, memilih dan memadukan berbagai jenis pendekatan serta pendekatan pembelajaran dalam menyampaikan materi. Hal ini bertujuan untuk mempermudah siswa dalam menerima materi yang disampaikan dan menghindari rasa jenuh siswa, sehingga diharapkan dengan menggunakan Pendekatan Communicative Language dalam pembelajaran tematik ini dapat meningkatkan pemahaman pada Materi Bercerita dengan kalimat efektif siswa Kelas 5 SD Negeri Airlangga I/198 Surabaya. Penelitian tindakan dilaksanakan dalam dua siklus pembelajaran dengan menerapkan Pendekatan Communicative Language dan hasil belajar siswa pada materi bercerita dengan kalimat efektif sebagai obyek penelitian. Berdasarkan paparan hasil penelitian dan pembahasan, dapat dirumuskan kesimpulan penelitian bahwa ada peningkatan hasil belajar Materi Bercerita dengan kalimat efektif melalui penerapan Pendekatan Communicative Language pada siswa Kelas 5 SD Negeri Airlangga I/198 Surabaya.
\end{abstract}

Kata kunci: Bercerita, Bahasa Baku, Pendekatan, Communicative Language

Copyright (c) 2021 Siti Romzah

Corresponding author: Siti Romzah

Email Address: romzah20@gmail.com (Jl. Gubeng Airlangga I No. 2, Kecamatan Gubeng, Kota Surabaya)

Received 09 September 2021, Accepted 06 October 2021, Published 19 November 2021

\section{PENDAHULUAN}

Setiap kurikulum yang telah berlaku di Indonesia dari periode sebelum tahun 1945 hingga kurukulum 2013, memiliki beberapa perbedaan sistem. Perbedaan sistem yang terjadi bisa merupakan kelebihan maupun kekurangan dari kurikulum itu sendiri. Kekurangan dan kelebihan tersebut dapat berasal dari landasan, komponen, evaluasi, prinsip, pendekatan, maupun model pengembangan kurikulum. Untuk memperbaiki kekurangan yang ada, maka disusunlah kurikulum yang baru yang 
diharapkan akan sesuai dengan kebutuhan masyarakat dan tuntutan zaman. Oleh karena itu, kurikulum di Indonesia akan senantiasa berkembang maupun berubah sesuai yang disebutkan sebelumnya.

Bahasa Indonesia sebagai salah satu bidang studi yang memiliki tujuan membekali siswa untuk mengembangkan bahasa di samping aspek penalaran dan hafalan sehingga pengetahuan dan informasi yang diterima siswa sebatas produk bahasa dan sastra. Padahal dalam proses belajar mengajar keterlibatan siswa secara totalitas, artinya melibatkan pikiran, penglihatan, pendengaran dan psikomotor (keterampilan, salah satunya sambil menulis). Jadi dalam proses belajar mengajar, seorang guru harus mengajak siswa untuk mendengarkan, menyajikan media yang dapat dilihat, memberi kesempatan untuk menulis dan mengajukan pertanyaan atau tanggapan, sehingga terjadi dialog kreatif yang menunjukkan proses belajar mengajar yang interaktif.

Berdasarkan latar belakang di atas penelitian ini mencoba untuk mengupas masalah rendahnya hasil belajar pada materi Bercerita dengan kalimat efektif yang dialami oleh siswa Kelas 5 SD Negeri Airlangga I/198 Surabaya. Penulis sebagai Guru Kelas bertanggung jawab untuk menemukan solusi untuk meningkatkan hasil belajar pada materi Bercerita dengan kalimat efektif. Perspektif yang diambil adalah meningkatkan aktivitas siswa pada proses belajar mengajar. Hal ini berkaitan dengan pemilihan pendekatan pembelajaran, oleh karenanya inovasi penerapan model dan pendekatan pembelajaran harus dilakukan melalui bentuk penerapan Pendekatan Communicative Language. Beberapa permasalahan dalam proses pembelajaran Bahasa Indonesia di Kelas 5 SD Negeri Airlangga I/198 yang dihadapi oleh penulis sebagai pengajar, antara lain dapat diidentifikasi sebagai berikut:

1. Di Kelas 5 untuk Materi Bercerita dengan kalimat efektif, dari 35 siswa yang mencapai ketuntasan belajar hanya $14 \%$ dengan rata-rata 53,8 .

2. Penerapan pendekatan pembelajaran yang konvensional dengan minimnya alat peraga yang digunakan.

3. Siswa yang tidak mencapai ketuntasan belajar sebagian besar memiliki persentase absen yang tinggi atau sering tidak masuk kelas dengan dan atau tanpa sebab.

Dari tiga permasalahan pembelajaran tersebut, penulis menganggap perlu adanya analisis masalah mana yang dianggap penting dan harus segera dipecahkan atau merupakan akar permasalahan yang sesungguhnya untuk kemudian diuraikan alternatif pemecahannya dengan konsep-konsep pembelajaran.

Salah satunya, guru -yang dalam hal ini penulis- dituntut untuk mampu menyesuaikan, memilih dan memadukan berbagai jenis pendekatan serta pendekatan pembelajaran dalam menyampaikan materi. Hal ini bertujuan untuk mempermudah siswa dalam menerima materi yang disampaikan dan menghindari rasa jenuh siswa, sehingga diharapkan dengan menggunakan Pendekatan Communicative Language dalam pembelajaran tematik ini dapat meningkatkan hasil belajar pada materi Bercerita dengan kalimat efektif Kelas 5 SD Negeri Airlangga I/198 Surabaya. 
Dari latar belakang yang telah dipaparkan di atas, dapat dirumuskan bahwa yang menjadi masalah dalam penelitian ini adalah sebagai berikut:

1. Apakah ada peningkatan hasil belajar pada materi Bercerita dengan kalimat efektif melalui penerapan Pendekatan Communicative Language pada siswa Kelas 5 SD Negeri Airlangga I/198 Surabaya?

2. Jika ada, seberapa besar peningkatan hasil belajar pada materi Bercerita dengan kalimat efektif melalui penerapan Pendekatan Communicative Language pada siswa Kelas 5 SD Negeri Airlangga I/198 Surabaya?

Dari rumusan masalah tersebut maka penelitian ini bertujuan:

1. Untuk mengetahui ada tidaknya peningkatan hasil belajar pada materi Bercerita dengan kalimat efektif melalui penerapan Pendekatan Communicative Language pada siswa Kelas 5 SD Negeri Airlangga I/198 Surabaya.

2. Untuk mengetahui seberapa besar peningkatan hasil belajar pada materi Bercerita dengan kalimat efektif melalui penerapan Pendekatan Communicative Language pada siswa Kelas 5 SD Negeri Airlangga I/198 Surabaya.

\section{Keterampilan Bercerita}

Bercerita merupakan kegiatan berbahasa yang bersifat produktif. Artinya, dalam bercerita seseorang melibatkan pikiran, kesiapan mental, keberanian, perkataan yang jelas sehingga dapat dipahami oleh orang lain. Menurut Burhan Nurgiyantoro (2001: 278), ada beberapa bentuk tugas kegiatan berbicara yang dapat dilatih untuk meningkatkan dan mengembangkan keterampilan bercerita pada siswa, yaitu (1) bercerita berdasarkan gambar, (2) wawancara, (3) bercakap-cakap, (4) berpidato, (5) berdiskusi.

Tarigan (1981: 35) menyatakan bahwa bercerita merupakan salah satu keterampilan berbicara yang bertujuan untuk memberikan informasi kepada orang lain. Dikatakan demikian karena bercerita termasuk dalam situasi informatif yang ingin membuat pengertian-pengertian atau maknamakna menjadi jelas. Dengan bercerita, seseorang dapat menyampaikan berbagai macam cerita, ungkapan berbagai perasaan sesuai dengan apa yang dialami, dirasakan, dilihat, dibaca dan ungkapan kemauan dan keinginan membagikan pengalaman yang diperolehnya.

Ketepatan kata dan kalimat sangat perlu dikuasai dalam bercerita, sebab dengan menggunakan kata dan kalimat yang tepat dalam bercerita akan memudahkan pendengar memahami isi cerita yang dikemukakan oleh pembicara. Isi cerita yang mudah dipahami akan menunjang dalam penyampaian maksud yang sama antara pembicara dan pendengar, sehingga tujuan penyampaian makna cerita juga dapat tercapai.

Selain itu dalam bercerita diperlukan kelancaran dalam menyampaikan kalimat per kalimat. Kelancaran dalam menyampaikan isi cerita akan menunjang pembicara dalam menyampaikan isi cerita secara runtut dan lancar sehingga penyimak/pendengar yang mendengarkan dapat antusias dan 
tertarik mendengarkan cerita.

Bercerita merupakan salah satu keterampilan berbahasa yang bersifat produktif yang berarti menghasilkan ide, gagasan, dan buah pikiran (Yeti Mulyati, 2009: 64). Ide, gagasan, dan pikiran seorang pembicara memiliki hikmah atau dapat dimanfaaatkan oleh penyimak/pendengar, misalnya seorang guru berbicara dalam mentransfer ilmu pengetahuan kepada siswa, sehingga ilmu tersebut dapat dipraktikkan dan dimanfaatkan oleh siswa dalam kehidupan sehari-hari.

Tarigan (1981: 17) mengungkapkan tiga tujuan umum dari kegiatan bercerita yaitu: (a) Memberitahukan dan melaporkan, (b) Menjamu dan menghibur, dan (c) Membujuk, mengajak, mendesak, dan meyakinkan. Sedangkan menurut Mudini dan Salamat Purba (2009: 4) tujuan bercerita meliputi: (a) Mendorong atau menstimulasi, (b) Meyakinkan, (c) Menggerakkan, (d) Menginformasikan, dan (e) Menghibur.

Menurut Bachtiar S. Bachri (2005: 11), mengatakan bahwa manfaat bercerita adalah dapat memperluas wawasan dan cara berfikir anak, sebab dalam bercerita anak mendapat tambahan pengalaman yang bisa jadi merupakan hal baru baginya. Bercerita merupakan kegiatan untuk menyampaikan pesan atau informasi kepada orang lain secara lisan. Dalam menyampaikan pesan atau informasi seorang pembicara harus memperhatikan faktor-faktor yang dapat menunjang keefektifan bercerita. Adapun faktor yang harus diperhatikan adalah faktor kebahasaan dan nonkebahasaan.

Arsjad dan Mukti (1993: 17-22) mengemukakan faktor-faktor kebahasaan dan nonkebahasaan yang dapat menunjang kekefektifan bercerita sebagai berikut: faktor kebahasaan meliputi : (a) ketepatan ucapan, (b) penekanana tekanan nada, sendi dan durasi, (c) pilihan kata, (d) ketepatan penggunaan kalimat, (e) ketepatan sasaran pembicaraan; faktor nonkebahasaan meliputi: (1) sikap yang wajar, tenang, dan tidak kaku, (2) pandangan harus diarahkan pada lawan bicara, (3) kesediaan menghargai pendapat orang lain, (4) gerak-gerik dan mimik yang tepat, (5) kenyaringan suara, (6) relevansi/penalaran, (7) penguasaan topik.

Sedangkan, faktor yang menghambat dalam keefektifan keterampilan bercerita yaitu: (a) faktor fisik, merupakan faktor yang ada dalam partisipan sendiri dan faktor yang berasal dari luar partisipan, (b) faktor media, terdiri dari faktor linguistik dan faktor nonlinguistik (misalnya tekanan, lagu, irama, ucapan dan isyarat gerak tubuh), (c) faktor psikologis, merupakan kondisi kejiwaan partisipan dalam keadaan marah, menangis, dan sakit.

Dalam kegiatan bercerita, perlu adanya suatu rencana untuk menentukan pokok-pokok cerita yang akan dikomunikasikan. Menurut Tarigan (1981: 32) dalam merencanakan suatu pembicaraan atau bercerita harus mengikuti langkah-langkah sebagai berikut:

1. Menentukan topik cerita yang menarik

2. Menyusun kerangka cerita dengan mengumpulkan bahan-bahan

3. Mengembangkan kerangka cerita

4. Menyusun teks cerita

Observasi yang digunakan dalam penelitian ini menggunakan observasi terstruktur dengan 
kerangka kerja yang telah disusun berdasarkan aspek-aspek dalam bercerita. Adapun aspek-aspek bercerita yang dinilai menurut Burhan Nurgiyantoro (2010: 410) meliputi (1) ketepatan isi cerita, (2) ketepatan penunjukkan detil cerita, (3) ketepatan logika cerita, (4) ketepatan makna seluruh cerita, (5) ketepatan kata, (6) ketepatan kalimat, dan (7) kelancaran.

\section{Pendekatan Communicative Language}

Yang dimaksud dengan Pendekatan Communicative Language adalah pengajaran bahas dengan pendekatan komunikatif seperti dikemukakan oleh Jack C. Richards dan Theodore S. Rodgers, bahwa: "the communicative approach ia language teaching starts from a theory of language as communication. The goal of language teaching is to develop what Hymes (1972) referred to as communicative competence". Pendekatan komunikatif ini lahir bermula dari pandangan tentang bahasa, bahwa bahasa adalah alat komunikasi. Menurut Hymes, teori tersebut menekankan tujuan akhir pengajaran bahasa adalah kemampuan komunikatif para siswa. Lebih lanjut, Hymes memperjelas bahwa yang dimaksud mengembangkan kemampuan komunikatif para siswa adalah halhal yang harus diketahui dalam berkomunikasi sehingga mereka mampu memerankan komunikasi dengan menggunakan bahasa sasaran dengan tepat.

Penekanan pendekatan komunikatif di sini, menurut para ahli bahasa bertujuan untuk: (1) menjadikan kemampuan komunikatif (communicative competence) sebagai tujuan pengajaran dalam pengajaran bahasa, (2) mengembangkan prosedur pengajaran yang menekankan keterkaitan keempat ketrampilan bahasa. Empat ketrampilan tersebut yaitu: reading (membaca), grammar/structure (susunan kata), writing (menulis), dan listening (mendengarkan).

Tujuan dari pendekatan ini senada dengan tujuan pembelajaran pada umumnya, yakni agar proses dan hasil belajar mengajar lebih berdaya guna dan berhasil guna dan menimbulkan kesadaran siswa untuk lebih semangat lagi menuntut ilmu.

Sedangkan manfaat dari pendekatan ini adalah sebagai berikut:

1. Memberikan pengalaman tentang macam-macam keterampilan membaca, yang didorong kecepatan aktivitas lainnya.

2. Mendorong anak didik untuk melakukan kerja kelompok, dan semakin cepat kerja kelompok semakin cepat pula kemajuannya.

3. Membantu siswa untuk membiasakan diri mendasarkan belajar pada sumber, bukan guru.

4. Sesuai bagi siswa dengan karakter kinestetik yang tidak dapat duduk diam dalam waktu yang relatif lama

Berikut ini adalah pacuan antar kelompok dalam menjalankan Pendekatan Communicative Language. Langkah-langkahnya adalah sebagai berikut:

1. Presentasi dialog singkat yang didahului dengan motivasi sekitar situasi dalam dialog tersebut. Contohnya dengan menanyakan pengalaman yang pernah dialami para siswa berkenaan dengan topik dialog tersebut. Pengajar dapat pula mendiskusikan tentang orang-orang yang terlibat 
dalam dialog tersebut, misalnya perannya, settingnya, pemakaian bahasanya dan lain-lain.

2. Praktek mengucapkan ujaran-ujaran yang tepat, baik secara individu, kelompok, seluruh kelas separuh kelas yang biasanya diperankan oleh pengajar terlebih dahulu.

3. Pertanyaan berdasarkan dialog yang dihubungkan dengan pengalaman sehari-hari dilanjutkan dengan variasi dari pengembangan kelas.

4. Mempelajari ungkapan-ungkapan komunikatif yang ada dalam kelas dialog tersebut dikontraskan dengan pengembangan yang mungkin telah dimiliki oleh para siswa.

5. Kesimpulan secara umum tentang fokus penggunaan komunikasi yang ada dalam dialog tersebut baik yang sering digunakan dalam bahasa lisan ataupun tertulis.

6. Kegiatan percakapan yang dilanjutkan dengan percakapan bebas.

7. Menirukan dialog tanpa teks di luar kelas yang dapat diperagakan dalam bentuk role-play.

8. Memberi pekerjaan rumah tertulis ataupun orally.

9. Evaluasi dengan bentuk ungkapan yang diperagakan secara oral

Telah dipaparkan di atas bahwa Pendekatan Communicative Language ini tidak semata-mata mengutamakan segi pelaksanaan atau aplikasi praktis. Namun tehnik pengajarannya dengan bantuan penggunaan tehnik pengajaran yang lain, antara lain ceramah, diskusi, tanya jawab, resitasi, dan lain-lain. Namun tetapi model atau pendekatan pembelajarannya menonjol pada aspek kecepatan siswa dalam beraktivitas (berfikir, membaca, menjawab, dan lain-lain). Tehnik-tehnik yang bisa digunakan sebagai pengantar pelaksanaan Pendekatan Communicative Language dalam pembelajaran yaitu dengan ceramah, diskusi, demonstrasi, resitasi, tanya jawab, drill, sosiodrama, karyawisata, simulasi, proyek.

Untuk memilih teknik mana yang akan digunakan sebagai pengantar pelaksanaan Pendekatan Communicative Language ini, tentu saja harus di perhatikan dan menjadikannya sebagai acuan pada syarat pemilihan pendekatan atau tehnik yang ada, agar tujuan pembelajaran yang telah ditetapkan sebelumnya dapat dicapai dengan maksimal. Jika dilihat dari alokasi waktu yang rata-rata diberikan sekolah itu hanya 2 jam pelajaran maka tehnik yang baik untuk melaksanakan pendekatan ini adalah dengan ceramah, tanya jawab, dan demonstrasi.

Seperti halnya model pembelajaran lain, Pendekatan Communicative Language memiliki kelebihan dan kekurangan. Kelebihan Pendekatan Communicative Language

1. Siswa diarahkan untuk terbiasa berpi kir terhadap bahan bacaan sehingga siswa menjadi lebih aktif dan teiatih untuk bisa membuat pertanyaan.

2. Siswa berusaha untuk memikirkan jawaban-jawaban dari pertanyaan yang mendalami isi bacaan atau teks tersebut.

3. Siswa dapat bekerjasama dalam kelompoknya untuk saling bertukar pendapat dalam memahami konsep materi yang disajikan dalam uraian teks

Adapun kekurangan Pendekatan Communicative Language antara lain:

1. Alokasi waktu yang digunakan untuk memahami sebuah teks dengan Pendekatan 
Communicative Language mungkin tidak banyak berbeda dengan mempelajari teks biasa.

2. Siswa sulit dikondisikan (ramai) saat berdiskusi dengan teman sebangkunya dalam mempelajari teks materi pelajaran.

\section{METODE}

\section{Setting Penelitian}

Penelitian Tindakan Kelas (PTK) merupakan suatu proses dinamis yang berlangsung dalam satu atau lebih siklus, dan masing-masing siklus terdiri dari empat momen (fase) dalam spiral perencanaan, tindakan (action), observasi, dan refleksi yang oleh Kemmis dan McTaggart (1988) diilustrasikan dalam model PTK spiral.

Dalam praktik, Kemmis dan McTaggart menyatakan model ini tidak boleh digunakan secara kaku, karena dalam kenyataan proses rencana-tindakan-observasi-refleksi tersebut tidak berlangsung serapi model tersebut. Fase-fase itu biasanya berlangsung tumpang tindih. Dengan demikian penulis dapat memperbaiki strategi tersebut secara optimal sehingga pengimplementasian strategi revisi ini nantinya dapat mencapai semua target keberhasilan. Strategi yang sudah diperbaiki (revised strategy) inilah yang menjadi fase perencanaan (plan) pada siklus berikutnya, yang nantinya diimplemetasikan, diobservasi, dan direfleksi kembali. Siklus tersebut dapat diulang beberapa kali hingga seluruh kriteria keberhasilan tercapai. Jumlah siklus tidak dapat diprediksi pada awal penelitian. Jika setelah siklus pertama semua kriteria keberhasilan dapat dicapai maka penelitian dapat dihentikan. Namun selama kriteria-kriteria keberhasilan itu belum tercapai, revisi terhadap strategi perlu dilakukan dan siklus berikutnya dilaksanakan.

\section{Subyek Penelitian}

Penelitian ini dilaksanakan oleh penulis di SD Negeri Airlangga I/198 Surabaya. Pelaksanaan penelitian dijadwalkan oleh penulis dengan rincian jadwal sebagai berikut:

Tabel 1. Waktu Pelaksanaan Tindakan

\begin{tabular}{|l|c|c|c|}
\hline \multicolumn{1}{|c|}{ Jenis Kegiatan } & Jan & Peb & Mar \\
\hline Konsultasi dengan Kepala Sekolah. & M1 & & \\
\hline Mengajukan proposal penelitian. & M1 & & \\
\hline Mengajukan RPP & M2 & & \\
\hline Revisi RPP. & M3 & & \\
\hline Evaluasi kualitas RPP tahap akhir. & M4 & & \\
\hline Konsultasi dengan Observer. & M4 & M1-4 & \\
\hline Pelaksanaan siklus I. & & M1-4 & \\
\hline Pelaksanaan siklus II. & & M1-4 & \\
\hline Menyusun laporan tindakan. & & & M1-3 \\
\hline
\end{tabular}

Kelas yang dijadikan obyek penelitian dan penelitian adalah Kelas 5 SDN Airlangga I/198 Surabaya 
yang masih aktif pada tahun pelajaran 2019/2020 yang berjumlah 35 siswa.

\section{Teknik Pengumpulan Data}

Pengumpulan data dari penelitian ini dilakukan dengan menggunakan (1) teknik dokumentasi, berupa data kelas, siswa dan perangkat pembelajaran guru, (2) teknik observasi, yang digunakan untuk mengukur atau menilai hasil dan proses belajar misalnya tingkah laku siswa pada proses belajar mengajar, serta (3) teknik tes yang digunakan secara tidak langsung. Dalam artian nilai tes dikonversikan sebagai bahan kajian kualitatif berdasarkan indikator yang dinilai.

\section{Validasi Data}

Validasi data juga dapat ditempuh dengan penganekaragaman alat pengumpul data. Semakin banyak data yang menguatkan didapat dengan alat pengumpul data yang berbeda maka data tersebut semakin valid. Sedangkan untuk memperoleh data yang mendukung keshahihan, serta sesuai denga fokus permasalahan dan tujuan yang hendak dicapai pada penelitian digunakan teknik validasi data. Untuk mendapatkan data yang mendukung dan sesuai dengan karakteristik fokus permasalahan dan tujuan penelitian, teknik validasi yang digunakan dalam penelitian ini adalah audit trail. triangulasi data. Triangulasi data yaitu mengecek keabsahan (validasi) data dengan mengkonfirmasikan data yang sama dari sumber yang berbeda untuk memastikan keabsahan (derajat kepercayaan).

Dari guru dilakukan pada saat pelaksanaan kegiatan inquiry learning balikan refleksi setelah pelaksanaan tindakan dan dengan data yang dijaring melalui lembar observasi teman guru/seIndonesiat dan kepala sekolah. Sedangkan dari siswa dilakukan kuesioner atau wawancara. Dari ahli dilakukan pada saat bimbingan mengenai temuan-temuan penelitian dan penyusunan laporan.

\section{Teknik Analisa Data}

Teknik analisis data adalah kegiatan mencermati, menguraikan, dan mengkaitkan setiap informasi yang terkait dengan kondisi awal, proses belajar, dan hasil pembelajaran untuk memperoleh simpulan tentang keberhasilan tindakan perbaikan pembelajaran.

\section{Teknik Analisis Data Kuantitatif}

Pada data-data kuantitatif seperti nilai hasil belajar, skor angket, persentase, distribusi frekuensi yang dapat dilakukan dengan 2 cara yaitu: (1) Analisis secara deskriptif, analisis ini dilakukan dengan cara seperti menghitung jumlah, rata-rata, nilai persentase, dan membuat grafik, (2) Analisis secara statistik, analisis ini dilakukan dengan cara seperti menghitung nilai beda terkecil dan nilai korelasi antar variabel.

Analisis data kuantitatif diperoleh dari hasil tes siswa yang bertujuan untuk mengetahui pemahaman siswa tentang materi pelajaran dari setiap siklus, di mana siswa secara individu telah belajar tuntas atau berhasil apabila sekurang-kurangnya mendapat nilai 70 (dengan nilai maksimal 100). 
Standar penentuan ketuntasan belajar siswa menurut Sudjana (2006:109) sebagai berikut:

$$
\mathrm{P}=\underset{\mathrm{N}}{\sum \mathrm{X}} \quad \mathrm{x} 100 \%
$$

Sedangkan untuk mencari persentase ketuntasan secara klasikal menggunakan rumus:

$$
\mathrm{P}=\sum \mathrm{n} \quad \times 100 \%
$$

\section{Teknik Analisis Data Kualitatif}

Pada data kualitatif dapat dilakukan analisis:

a. Analisis Interaktif. Analisis ini dilakukan dengan: (1) memilih atau mereduksi data terhadap hasil temuan data yang relevan dengan penelitian diambil sementara data yang tidak relevan dibuang, (2) mendeskripsikan semua data yang relevan hasil temuan, dan (3) menarik kesimpulan berdasarkan deskripsi hasil temuan, serta (4) melakukan verifikasi

b. Analisis dengan mencari pola. Analisis ini dilakukan dengan cara mencarai pola berdasarkan hasil refleksi dari guru, kemudian digabung dengan data-data yang diperoleh pengamat pada saat observasi.

Dalam sebuah penelitian, perhatian lebih pada kasus daripada sampel. Hal ini berimplikasi bahwa metodologi yang dipakai lebih dapat diterpkan terhadap pemahaman situasi problematik dari pada atas dasar prediksi di dalam parameter. Analisis data dalam penelitian Kualitatif menggunakan statistik. Ada 2 macam statistik yang digunakan untuk analisis data dalam penelitian yaitu statistik deskriptif dan statistik inferensial.

Statistik deskriptif adalah ststistik yang digunakan untuk menganalisis data dengan cara mendeskripsikan atau menggambarkan data yang telah terkumpul sebagai mana adanya tanpa bermaksud membuat kesimpulan yang berlaku umum. Penelitian yang dilakukan pada populasi (tanpa diambil sampelnya), jelas akan menggunakan ststistik deskriptif dalam menganalisisnya. Termasuk dalam ststistik deskriptif antara lain pengujian data melalui tabel, grafik, diagram lingkaran, pictogram. Perhitungan modus, median, mean, desil, persentil, perhitungn penyebaran data dan perhitungan persentase.

Statistik inferensial (sering juga disebut statistik induktif atau statistik probabilita) adalah teknik statistik yng digunakan untuk menganilisa data sampel dan hasilnya diberlakukan untuk populasi. Statistik ini akan cocok digunakan oleh sampel diambil dari populasi secara random.

Salah satunya diterapkan pada instrumen lembar observasi. Lembar observasi yang diisi oleh pengamat pada saat mengamati proses pembelajaran berlangsung, baik pengamatan terhadap aktivitas guru maupun pengamatan terhadap aktivitas siswa dengan menggunakan rumus sebagai berikut:

$$
\mathrm{P}=\underline{\mathrm{f}} \times 100 \%
$$

Pengelolahan kegiatan belajar mengajar dianalisis dengan ketentuan sebagai berikut: 
$1=$ Kurang sekali

$2=$ Kurang

$3=$ Baik

4 = Baik sekali

Data pengamatan dianalisis dengan menghitung rata-rata pada setiap siklus yang dilaksanakan, selanjutnya nilai rata-rata tersebut diklasifikasikan dengan kriteria sebagai berikut:

$76-100 \%=$ Sangat baik.

$66-75 \%=$ Baik.

$46-65 \%=$ Cukup.

$0-45 \%=$ Kurang.

\section{Indikator Kinerja}

Indikator-indikator untuk menilai aktivitas guru adalah sebagai berikut:

Tabel 2. Indikator Aktivitas Guru (Diisi Oleh Observer atau Kepala Sekolah)

\begin{tabular}{|l|l|}
\hline No & \multicolumn{1}{|c|}{ Indikator yang Dinilai } \\
\hline 1 & Presentasi cerita dengan kalimat efektif. \\
\hline 2 & Mengajukan pertanyaan berdasarkan cerita. \\
\hline 3 & Mengembangkan ungkapan-ungkapan komunikatif. \\
\hline 4 & Memberi kesempatan bagi siswa untuk bercerita, siswa lain berpendapat. \\
\hline 5 & Melaksanakan evaluasi. \\
\hline
\end{tabular}

Sedangkan indikator-indikator untuk menilai prestasi belajar siswa adalah sebagai berikut:

Tabel 3. Indikator Prestasi Belajar Siswa

\begin{tabular}{|c|l|}
\hline No & \multicolumn{1}{|c|}{ Indikator yang Dinilai } \\
\hline 1 & Memperhatikan presentasi guru tentang cerita dengan kalimat efektif. \\
\hline 2 & Melakukan tanya jawab berdasarkan cerita secara aktif. \\
\hline 3 & Mengimplementasikan ungkapan-ungkapan komunikatif. \\
\hline 4 & Aktif dalam kegiatan bercerita. \\
\hline 5 & Menyimpulkan materi tentang bahasa baku. \\
\hline
\end{tabular}

\section{Diskusi}

\section{Deskripsi Kondisi Awal}

Rekapitulasi Nilai Pre-Test Materi Bercerita dengan kalimat efektif Siswa Kelas 5 yang dilakukan sebelum penelitian tindakan memiliki rata-rata 53,8 dengan hanya 5 orang siswa dari 35 orang siswa yang telah mencapai Ketuntasan Belajar Minimal (KBM) sehingga ketuntasan klasikal hanya mencapai $14 \%$.

\section{Deskripsi Siklus I}


Pembelajaran pada siklus I dilaksanakan dalam waktu 2 × 3 × 25 menit. Pertemuan siklus I direncanakan pada tanggal 6 dan 13 Oktober 2021, jam pelajaran 1 sampai dengan 3, dengan materi Bercerita dengan kalimat efektif.

Kegiatan pembelajaran yang dilakukan ini sesuai dengan langkah-langkah Pendekatan Communicative Language sebagai berikut:

1. Presentasi dialog singkat yang didahului dengan motivasi sekitar situasi dalam dialog tersebut. Contohnya dengan menanyakan pengalaman yang pernah dialami para siswa berkenaan dengan topik dialog tersebut. Pengajar dapat pula mendiskusikan tentang orang-orang yang terlibat dalam dialog tersebut, misalnya perannya, settingnya, pemakaian bahasanya dan lain-lain.

2. Praktek mengucapkan ujaran-ujaran yang tepat, baik secara individu, kelompok, seluruh kelas separuh kelas yang biasanya diperankan oleh pengajar terlebih dahulu.

3. Pertanyaan berdasarkan dialog yang dihubungkan dengan pengalaman sehari-hari dilanjutkan dengan variasi dari pengembangan kelas.

4. Mempelajari ungkapan-ungkapan komunikatif yang ada dalam kelas dialog tersebut dikontraskan dengan pengembangan yang mungkin telah dimiliki oleh para siswa.

5. Kesimpulan secara umum tentang fokus penggunaan komunikasi yang ada dalam dialog tersebut baik yang sering digunakan dalam bahasa lisan ataupun tertulis.

6. Kegiatan percakapan yang dilanjutkan dengan percakapan bebas.

7. Menirukan dialog tanpa teks di luar kelas yang dapat diperagakan dalam bentuk role-play.

8. Memberi pekerjaan rumah tertulis ataupun orally.

9. Evaluasi dengan bentuk ungkapan yang diperagakan secara oral.

\section{Deskripsi Siklus II}

Pembelajaran pada siklus I dilaksanakan dalam waktu 2 x 3 x 25 menit. Pertemuan siklus II direncanakan pada tanggal 21 dan 27 Oktober 2021, jam pelajaran 1 sampai dengan 3, dengan materi Bercerita dengan kalimat efektif. Kegiatan pembelajaran yang dilakukan ini sesuai dengan langkahlangkah Pendekatan Communicative Language sebagai berikut:

1. Presentasi dialog singkat yang didahului dengan motivasi sekitar situasi dalam dialog tersebut. Contohnya dengan menanyakan pengalaman yang pernah dialami para siswa berkenaan dengan topik dialog tersebut. Pengajar dapat pula mendiskusikan tentang orang-orang yang terlibat dalam dialog tersebut, misalnya perannya, settingnya, pemakaian bahasanya dan lain-lain.

2. Praktek mengucapkan ujaran-ujaran yang tepat, baik secara individu, kelompok, seluruh kelas separuh kelas yang biasanya diperankan oleh pengajar terlebih dahulu.

3. Pertanyaan berdasarkan dialog yang dihubungkan dengan pengalaman sehari-hari dilanjutkan dengan variasi dari pengembangan kelas.

4. Mempelajari ungkapan-ungkapan komunikatif yang ada dalam kelas dialog tersebut dikontraskan dengan pengembangan yang mungkin telah dimiliki oleh para siswa. 
5. Kesimpulan secara umum tentang fokus penggunaan komunikasi yang ada dalam dialog tersebut baik yang sering digunakan dalam bahasa lisan ataupun tertulis.

6. Kegiatan percakapan yang dilanjutkan dengan percakapan bebas.

7. Menirukan dialog tanpa teks di luar kelas yang dapat diperagakan dalam bentuk role-play.

8. Memberi pekerjaan rumah tertulis ataupun lisan

9. Evaluasi dengan bentuk ungkapan yang diperagakan secara lisan

Selain bagi siswa, Pendekatan Communicative Language ini merupakan hal yang menyenangkan bagi penulis sehingga pembelajaran menjadi hidup dan aktivitas siswa dalam belajar semakin meningkat. Pendekatan Communicative Language ini harus dilaksanakan secara berkesinambungan sebagai upaya pembiasaan bagi siswa.

Penilaian observer tentang Aktivitas Guru pada Siklus I termasuk dalam kategori baik. Hal ini terlihat pada tahap pembelajaran kegiatan awal. Hal ini dipengaruhi oleh kemampuan guru dalam memotivasi siswa. Pada tahap kegiatan inti guru masih belum bisa melakukan improvisasi dan belum mengerti tentang langkah-langkah penyelesaian dalam pemecahan. Maka dari tinjauan ini, observer menyimpulkan bahwa pada tahap kegiatan Siklus I, tampaknya guru masih perlu bimbingan dalam hal mengimprovisasi langkah demi langkah dari pendekatan yang digunakan.

Dan berdasarkan hasil observasi pada indikator aktivitas dan hasil, dapat disimpulkan bahwa pada siklus I rata-rata nilai hasil belajar pada materi Bercerita dengan kalimat efektif siswa adalah 71,3 dan rata-rata kemampuan siswa dalam melaksanakan Pendekatan Communicative Language adalah 13,8 atau 69\%. Hal ini bila diinterpretasikan ke dalam tabel interpretasi dengan rata-rata 71,3 maka termasuk ke dalam kategori baik.

Sedangkan siswa yang tuntas berjumlah 21 siswa, dan siswa yang belum tuntas berjumlah 14 orang. Dari perhitungan berdasarkan banyak siswa yang tuntas, maka dapat disimpulkan bahwa ketuntasan klasikal pada siklus I sebesar 60\% dengan kategori cukup. Selanjutnya pada siklus II, penilaian observer tentang Aktivitas Guru termasuk dalam kategori sangat baik. Hal ini terlihat pada tahap pembelajaran kegiatan awal. Hal ini dipengaruhi oleh kepandaian guru dalam memotivasi siswa. Pada tahap kegiatan inti guru telah berhasil melakukan improvisasi pada langkah-langkah penyelesaian. Maka dari tinjauan ini, observer menyimpulkan bahwa pada tahap kegiatan Siklus II secara global berjalan dengan lancar. Dan berdasarkan hasil observasi pada indikator aktivitas dan hasil, dapat disimpulkan bahwa pada siklus II rata-rata nilai hasil belajar pada materi Bercerita dengan kalimat efektif siswa adalah 77,7 dan rata-rata kemampuan siswa dalam melaksanakan Pendekatan Communicative Language adalah 15,2 atau 76\%. Hal ini bila diinterpretasikan ke dalam tabel interpretasi dengan rata-rata 77,7 maka termasuk ke dalam kategori baik.

Sedangkan siswa yang tuntas berjumlah 29 siswa, dan siswa yang belum tuntas berjumlah 6 orang. Dari perhitungan berdasarkan banyak siswa yang tuntas, maka dapat disimpulkan bahwa ketuntasan klasikal pada siklus II sebesar 83\% dengan kategori sangat baik. Dengan demikian penerapan Pendekatan Communicative Language memiliki efektifitas untuk meningkatkan nilai autentik dan 
hasil belajar pada materi Bercerita dengan kalimat efektif siswa. Hal ini terlihat dari tanjakan persentase hasil belajar pada materi Bercerita dengan kalimat efektif siswa dari sebelum diterapkan pendekatan pembelajaran ini yang hanya memiliki rata-rata 53,8 menjadi 71,3 pada siklus I dan 77,7 pada siklus II.

Peningkatan kemampuan siswa dalam melaksanakan Pendekatan Communicative Language sebesar $24 \%$ dari dua siklus ini jika ditelusuri lebih dalam adalah karena adanya faktor motivasi dari dalam diri siswa itu sendiri, apakah mereka mau menunjukkan seluruh aktivitas belajar yang menjadi indikator penelitian sepenuh hati mereka atau tidak. Model dan pendekatan pembelajaran yang diterapkan hanyalah faktor stimulus untuk memunculkan pembiasaan pada diri siswa.

Anggapan penulis ini tentu saja masih perlu dibuktikan dengan penelitian tindakan kelas lanjutan dari penelitian ini tiga atau empat bulan ke depan untuk menilai apakah pembiasaan dengan penggunaan model dan pendekatan pembelajaran tertentu memiliki signifikansi yang besar terhadap peningkatan hasil belajar pada materi Bercerita dengan kalimat efektif siswa.

\section{KESIMPULAN}

Berdasarkan paparan hasil penelitian dan pembahasan, dapat dirumuskan kesimpulan yaitu: Ada peningkatan hasil belajar pada materi Bercerita dengan kalimat efektif melalui penerapan Pendekatan Communicative Language pada siswa Kelas 5 SD Negeri Airlangga I/198 Surabaya. Peningkatan hasil belajar pada materi Bercerita dengan kalimat efektif melalui penerapan Pendekatan Communicative Language pada siswa Kelas 5 SD Negeri Airlangga I/198 Surabaya rata-rata sebesar 24\%. Dari hasil kesimpulan maka penulis sampaikan bahwa penerapan Pendekatan Communicative Language ini dapat meningkatkan hasil belajar pada materi Bercerita dengan kalimat efektif siswa dan membutuhkan langkah tindak lanjut dan pembiasaan agar terbentuk karakter yang baik pada diri siswa agar kelak berguna bagi bangsa, negara dan agamanya.

Oleh kerenanya, penulis memberikan beberapa saran agar persepsi negatif siswa terhadap suasana proses belajar mengajar yang menjenuhkan segera berubah, Guru Kelas harus kreatif dengan menerapkan berbagai model dan pendekatan pembelajaran yang PAKEMIP, guru Kelas seyogyanya sering memberi peluang kepada siswanya untuk berkomunikasi antarteman, guru dan masyarakat sekolah, tentang materi ajar, serta orang tua harus turut dilibatkan karena bagaimanapun juga 83\% waktu sehari semalam siswa dihabiskan di luar sekolah yang sepenuhnya adalah tanggung jawab orang tua.

\section{UCAPAN TERIMA KASIH}

Terimakasih saya ucapkan kepada Kepala Sekolah dan Guru-guru di SDN Airlangga I/198 Surabaya yang telah memberikan kesempatan kepada peneliti dalam melaksanakan penelitian. Selain itu juga kepada seluruh stakeholder yang telah ikut berpartisipasi dalam 
Meningkatkan Hasil Belajar Materi Bercerita Dengan Kalimat Efektif Dengan Menerapkan Pendekatan Communicative Language, Siti Romzah

melaksanakan penelitian ini

\section{REFERENSI}

Arikunto, Suharsimi. 2002. Prosedur Penelitian Suatu pendekatan Praktek. Jakarta: Rineka Cipta

Arsjad, Maidar G dan Mukti U.S. 1993. Pembinaan Keterampilan Berbicara Bahasa. Indonesia. Jakarta: Erlangga.

Bachir, Bachtiar S. 2005. Pengembangan Kegiatan Bercerita di Taman Kanak-Kanak dan Teknik dan Prosedurnya. Jakarta: Depdiknas.

Burhan, Nurgiyantoro. 2001. Penilaian dalam Pengajaran Bahasa dan Sastra. Yogyakarta: BPFE Yogyakarta.

Sudjana, Nana. 2006. Penilaian Hasil Proses Belajar Mengajar. Bandung: Remaja Rosdakarya Tarigan, H.G. 1981. Berbicara. Bandung: Angkasa.

Yeti, Mulyati. 2009. Keterampilan Berbahasa Indonesia. Jakarta: Universitas Terbuka 